\title{
PENGARUH STABILISASI PKL SHELTER MANAHAN TERHADAP KINERJA JALAN MENTERI SUPENO SURAKARTA
}

\author{
Faisal Indra Permana ${ }^{1}$, Galing Yudana ${ }^{1}$, Paramita Rahayu ${ }^{1}$ \\ 1 Program Studi Perencanaan Wilayah dan Kota Fakultas Teknik Universitas Sebelas Maret Surakarta
}

\begin{abstract}
Abstrak
Stabilisasi merupakan salah satu program penataan PKL pemerintah kota Surakarta yang berfungsi untuk memberi legalitas pada PKL di suatu kawasan dengan memfasilitasi tempat dagang permanen dan sejumlah fasilitas penunjang salah satunya seperti parkir on street. Adanya program stabilisasi berpotensi menimbukan permasalahan baru seperti dampak berupa beban transportasi di jalan sekitarnya. Salah satu PKL stabilisasi di kota Surakarta tersebut adalah PKL shelter Manahan. Penelitian ini bertujuan untuk mengetahui bagaimana pengaruh stabilisasi PKL shelter Manahan terhadap kinerja jalan Menteri Supeno. Tahap pertama penelitian yaitu mengidentifikasi aktivitas PKL shelter yang memicu pergerakan yang mempengaruhi besar volume kendaraan jalan Menteri Supeno. Tahap kedua yaitu menganalisis volume kendaraan jalan Menteri Supeno. Tahap ketiga mengidentifikasi kondisi parkir on street yang mempengaruhi kapasitas jalan Menteri Supeno. Tahap selanjutnya, menganalisis kapasitas jalan Menteri Supeno. Kemudian menganalisis kinerja jalan Menteri Supeno yang dilanjut dengan mengidentifikasi pengaruh PKL stabilisasi Manahan terhadap kinerja jalan Menteri Supeno. Hasil akhir penelitian ini adalah teridentifikasinya pengaruh yang dimulai dari aktivitas PKL shelter membangkitkan pergerakan menyebabkan peningkatan volume kendaraan, disisi lain keberadaan parkir on street PKL shelter mengalami kekurangan daya tampung yang secara signifikan menurunkan kapasitas jalan menyebabkan kemampuan jalan Menteri Supeno dalam menampung beban lalulintas berkurang, semua hal tersebut berkolaborasi dalam menurunkan nilai kinerja jalan sehingga jalan Menteri Supeno mengalami penurunan kualitas. Pada akhirnya diperoleh hasil bahwa keberadaan stabilisasi PKL shelter Manahan mempengaruhi kinerja jalan Menteri Supeno.
\end{abstract}

Kata Kunci: kinerja jalan; PKL shelter; stabilisasi

\begin{abstract}
Stabilization is one of the arrangement program of city government street vendors Surakarta that serves to give legality to street vendors in a region by facilitating permanent place of trade and a number of supporting facilities such as parking on street. The existence of a stabilization program has the potential to generate new problems such as the impact of transportation loads on the surrounding roads. One of the PKL stabilization in the city of Surakarta is PKL shelter Manahan. This study aims to find out how the effect of PKL shelter stabilization Manahan against the performance of Menteri Supeno's road. The first phase of the research is to identify the activities of street vendors that trigger the movement that affect the volume of road vehicles Menteri Supeno. The second stage is to analyze the volume of road vehicles Menteri Supeno. The third phase identifies on-street parking conditions that affect the capacity of the Menteri Supeno's road. The next stage, analyzing the capacity of Menteri Supeno's road. Then analyzed the performance of Menteri Supeno's road continued by identifying the effect of the Manahan Stabilization Street vendors on the performance of Menteri Supeno's road. The end result of this research is the identification of the effect that started from the activity of street vendors shelter generates movement causing the increase of vehicle volume, on the other side existence of parking on street PKL shelter experiencing lack of capacity which significantly decrease the capacity of road causing capability of Menteri Supeno road in accommodating the load of traffic decrease, all It collaborated in lowering the performance of the road so that the Menteri Supeno's road was decreasing quality. In the end, it was found that the existence of stabilization of PKL shelter Manahan influenced the performance of Menteri Supeno's road.
\end{abstract}

Keywords: road perfomance; shelter street vendors; stabilization

\section{PENDAHULUAN}

Urbanisasi memicu terbentuknya sektor informal oleh masyarakat ekonomi menengah kebawah, hal ini mengakibatkan tidak terkendalinya pertumbuhan sektor informal dalam hal ini adalah PKL (Hariyono, 2007). Berkembangnya jenis usaha PKL di perkotaan menimbulkan dua sudut pandang (McGee, 1973). Pertama adalah sudut pandang positif, mendorong rasa berwirausaha yang memicu pertumbuhan ekonomi perkotaan khususnya di negara berkembang. Kedua adalah sudut pandang negatif, keberadaan PKL menghambat ekonomi dari sisi ketidaktertiban dan kebersihan kota. Salah satu kota dengan jumlah PKL terbanyak yaitu kota Surakarta. Pada tahun 2014 jumlah PKL 
mencapai $2920 \mathrm{PKL}$, dengan perkiraan jumlah yang meningkat disetiap tahunnya (Rahayu. Et.al, 2014). PKL di kota Surakarta diatur pada perda Surakarta No. 3 Tahun 2011 tentang PKL, namun pada pelaksanaanya masih jauh dari apa yang diatur pada perda tersebut. Sehingga, pemerintah kota Surakarta menginisiasi program penataan PKL diantaranya relokasi dan stabilisasi. Relokasi dinilai lebih signifikan mengurangi permasalahan PKL dibandingkan dengan stabilisasi, karena bukan hanya dari segi estetika saja seperti penyediaan lapak dagang yang legal melainkan ada beberapa fasilitas pendukung yang optimal dalam mendukung keberlangsungan aktivitas PKL (Rahayu. Et.al, 2014).

Salah satu fasilitas pendukung PKL yang dimaksud adalah jenis parkir. Pada relokasi jenis parkir adalah off street, berada pada gedung atau area pasar, sehingga tidak menganggu arus lalu lintas jalan sekitar, sedangkan stabilisasi yaitu on street dengan memanfaatkan bahu jalan sebagai lahan parkir, sehingga masih menimbulkan dampak bagi jalan sekitar berupa penurunan kapasitas jalan. Salah satu stabilisasi PKL di kota Surakarta adalah PKL shelter Manahan, karena hampir semua karakteristik berlokasi PKL ada disana. Pada awalnya PKL Manahan berlokasi di tepi jalan Adi Sucipto (depan stadion manahan) namun, karena ada larangan tentang keberadaan PKL di jalan kolektor sekunder, maka dipindah di jalan Menteri Supeno berfungsi jalan lokal (belakang stadion manahan). Dipindahkannya PKL ini menimbulkan permasalahan baru salah satunya memicu pergerakan. Jika dilihat lebih luas kawasan Manahan memiliki variasi aktifitas yang cukup banyak diantaranya adalah aktifitas olahraga, perkantoran, pendidikan, perdagangan dan jasa. Sehingga, kawasan belakang Manahan dinilai menarik bagi PKL baru untuk berjualan.

Seiring berjalannya waktu banyak PKL baru yang berjualan di ruas jalan Menteri Supeno yang kemudian menimbulkan kesemrawutan, dengan adanya hal tersebut pemerintah melakukan penataan dengan membuat shelter bagi PKL yang lama. Program ini merupakan stabilisasi PKL yang secara estetika dinilai berhasil karena bisa menata PKL secara rapi, namun fasilitas pendukung yang berupa parkir on street berisiko menurunkan kapasitas jalan Menteri Supeno. Selain itu, adanya PKL shelter sebagai aktifitas baru dapat menimbulkan bangkitan tarikan yang berpengaruh pada volume kendaraan. MKJI (1997), kinerja jalan diperoleh melalui perbandingan dari volume kendaraan terhadap kapasitas jalan. Jika volume kendaraan tinggi dibagi oleh nilai kapasitas jalan yang rendah maka akan menurunkan kinerja jalan. Dari uraian di atas maka perlu adanya penelitian yang bertujuan untuk mengetahui pengaruh stabilisasi PKL shelter Manahan terhadap kinerja jalan Menteri Supeno Surakarta.

\section{KAJIAN TEORI}

Stabilisasi bertujuan menyediakan lokasi berdagang berupa kantong-kantong bagi Pedagang Kaki Lima (PKL) rapi dan legal (RTRW Kota Surakarta, 2011-2031), sehingga mengurangi kecenderungan PKL menempati lokasi yang bukan diperuntukan bagi mereka. Stabilisasi mengikuti karakteristik berlokasi PKL pada umumnya (Mc. Gee dan Yeung, 1977). PKL stabilisasi memiliki pola pelayanan aktivitas yang berpotensi membangkitkan pergerakan, meliputi: waktu pelayanan, PKL memiliki rentang waktu melayani pengunjungnya, waktu pelayanan menyesuaikan jenis aktivitas di sekitar kawasan, semakin bervariasi jenis aktivitas PKL semakin lama waktu pelayanannya (Haryanti, 2008). Selain itu, PKL memiliki skala pelayanan merupakan jangkauan pelayanan PKL dalam melayani para pelanggannya, semakin jauh skala pelayanan semakin besar jangkauannya (Haryanti, 2008). Dalam melayani para pengunjungnya PKL memiliki pola keruangan yang memudahkan para pelangganya mengakses PKL yaitu memanjang dengan mengikuti pola jaringan jalan di sekitar pusat aktivitas pada suatu kawasan (Mc. Gee dan Yeung, 1977). Selain tiga hal diatas, homogenitas jenis dagangan PKL juga berpotensi memicu pergerakan. Diturunkan dari karakter berlokasi PKL yang mendekati PKL komoditas sejenis teraglomerasi di suatu kawasan, adanya PKL ini tidak bisa dipisahkan oleh kawasan yang ditempati/ embedded (Mc. Gee dan Yeung, 1977). Aglomerasi merupakan keuntungan yang diperoleh ketika sejumlah tempat usaha sejenis membentuk cluster di suatu kawasan menjadi satu aktivitas yang baru (Edward, 2010). Sama halnya dengan PKL stabilisasi yang mengelompok pada suatu kawasan, keberadaan mereka mengundang PKL baru untuk berdatangan di sekitar tempat usaha mereka, namun itu menjadi satu catatan bagi pemerintah lokal karena lahan yang disediakan untuk stabilisasi belum bisa mengakomodir para PKL baru yang berdatangan di sekitar kawasan tersebut sehingga kerap kali keberadaan PKL baru ini menganggu karena menempati tempat umum seperti bahu jalan, trotoar, pintu masuk (pasar, stadion dll) dan pedestrian (Roever, 2014).

Rahayu Et. al (2014), pasca penataan PKL pada program stabilisasi tidak sepenuhnya berhasil, melainkan masih ada beberapa permasalahan salah satunya terbatasnya kapasitas lahan parkir. Mayoritas stabilisasi PKL berada di pinggir jalan, sehingga lahan parkir umumnya memanfaatkan bahu jalan/ on street. Adanya parkir on street merupakan masalah lalu lintas karena secara signifikan menurunkan kapasitas jalan yang berimbas pada kinerja jalan (Wahyuni, 2008). Mataram (2011), dalam mengetahui pengaruh bangkitan pergerakan terhadap kinerja jalan yaitu dengan membandingkan kinerja jalan saat pasar beroperasi dan saat pasar tidak beroperasi. Penelitian ini dapat diturunkan dalam mengetahui pengaruh stabilisasi PKL terhadap kinerja jalan. Keberadaan pasar diturunkan sebagai PKL 
Stabilisasi, dalam mengetahui pengaruhnya dilakukan dengan membandingkan kinerja jalan pada ruas jalan dengan PKL stabilisasi dan tanpa PKL stabilisasi. Bangkitan pergerakan dipengaruhi oleh jenis aktivitas yang ada di suatu kawasan, semakin bervariasi jenis aktivitasnya semakin besar bangkitan pergerakannya (Tamin, 2000). Secara teknis tinggi rendahnya bangkitan pergerakan dapat dilihat dari kecenderungan volume kendaraan dan kapasitas jalan yang ada (Mataram, 2011). Dari kedua teori di atas dapat disimpulkan bahwa bangkitan pergerakan dipengaruhi oleh aktivitas kawasan yang secara statistik diketahui dari tinggi rendahnya volume kendaraan dan kapasitas jalan. Pada teori diturunkan bahwa bangkitan pergerakan terjadi oleh aktivitas PKL stabilisasi diketahui dari kecenderungan volume kendaraan yang terjadi dan secara langsung parkir on street mempengaruhi penurunan kapasitas jalan. Adanya dua komponen dapat digunakan untuk menghitung kinerja jalan untuk mengetahui pengaruh.

\section{METODE PENELITIAN}

Penelitian ini berjenis penelitian deskriptif dengan menggunakan metode kuantitatif. Data yang digunakan adalah data sekunder berupa studi literatur dan data primer berupa survei, observasi dan kuesioner. Populasi dalam penelitian ini adalah pedagang PKL shelter, pengunjung yang termasuk undefined population dan petugas parkir on street. Analisis disesuaikan dengan sasaran penelitian yang terbagi menjadi empat tahap, yaitu sebagai berikut :

1) Analisis aktifitas PKL shelter Manahan sebagai pemicu bangkitan pergerakan

Terdapat empat analisis dalam mengidentifikasi aktifitas PKL sebagai pemicu bangkitan pergerakan yang seluruhnya menggunakan analisis statistik deskriptif, berikut adalah analisisnya :

Tabel 1. Analisis aktifitas PKL shelter Manahan sebagai pemicu bangkitan pergerakan

\begin{tabular}{|c|c|c|c|c|}
\hline No & Analisis & Input & Proses & Output \\
\hline 1 & $\begin{array}{l}\text { Waktu pelayanan } \\
\text { Sumber : Haryanti, } \\
2008\end{array}$ & $\begin{array}{l}\text { - Rentang waktu PKL } \\
\text { banyak dikunjungi } \\
\text { pelanggan } \\
\text { - Jam buka dan tutup } \\
\text { PKL stabilisasi } \\
\text { Manahan }\end{array}$ & $\begin{array}{l}\text { Menyesuaikan temuan lapangan dengan } \\
\text { teori rentang waktu pelayanan PKL } \\
\text { (Haryanti, 2008) : } \\
\text { - Berangkat kerja (07.00 - 08.00 WIB) } \\
\text { - Istirahat (12.00 - } 13.00 \text { WIB) } \\
\text { - Pulang kerja ( } 16.00-17.00 \text { WIB) } \\
\text { Selain itu, juga mengidentifikasi rentang } \\
\text { waktu PKL ramai dikunjungi pelanggan } \\
\text { (peak time) dari tiga kondisi di atas. }\end{array}$ & $\begin{array}{l}\text { - Rata-rata waktu } \\
\text { pelayanan PKL } \\
\text { stabilisasi Manahan } \\
\text { - Diagram persentase } \\
\text { rentang waktu peak } \\
\text { time pelanggan }\end{array}$ \\
\hline 2 & $\begin{array}{l}\text { Skala pelayanan } \\
\text { Sumber : Haryanti, } \\
2008\end{array}$ & $\begin{array}{l}\text { - Data tempat tinggal } \\
\text { dan jarak /tempat } \\
\text { kerja/lokasi aktivitas } \\
\text { pengunjung dengan } \\
\text { PKL Stabilisasi }\end{array}$ & $\begin{array}{l}\text { Mengklasifikasikan asal pengunjung : } \\
\text { - Dalam kota }(<3 \mathrm{~km}) \\
\text { - Dalam kota }(>3 \mathrm{~km}) \\
\text { - Luar kota }(>3 \mathrm{~km}) \\
\text { kemudian dijelaskan kecenderungan } \\
\text { yang ada dilapangan }\end{array}$ & $\begin{array}{l}\text { Diagram skala pelayanan } \\
\text { PKL stabilisasi Manahan } \\
\text { yang disesuaikan dengan } \\
\text { tiga kriteria }\end{array}$ \\
\hline 3 & $\begin{array}{l}\text { Pola sebaran PKL } \\
\text { memanjang } \\
\text { Sumber : } \\
\text { Ray dan Mishra, } \\
2011\end{array}$ & $\begin{array}{l}\text { - } \text { Persebaran PKL } \\
\text { stabilisasi dan aktifitas } \\
\text { sekitar } \\
\text { - Jarak PKL dengan } \\
\text { aktifitas sekitar }\end{array}$ & $\begin{array}{l}\text { Memetakan persebaran PKL stabilisasi } \\
\text { dan aktifitas di sekitarnya dengan Arc } \\
\text { Gis, kemudian mengukur jarka antara } \\
\text { PKL stabilisasi dengan masing-masing } \\
\text { aktifitas yang ada }\end{array}$ & $\begin{array}{l}\text { Peta pola sebaran PKL } \\
\text { stabilisasi dengan jarak } \\
\text { terhadap aktifitas di } \\
\text { sekitarnya }\end{array}$ \\
\hline 4 & $\begin{array}{l}\text { Homogenitas jenis } \\
\text { dagangan } \\
\text { Sumber: } \\
\text { Mc Gee dan } \\
\text { Young, } 1977 \\
\text { Edward, } 2010\end{array}$ & $\begin{array}{l}\text { - Jumlah dan jenis } \\
\text { dagangan PKL } \\
\text { stabilisasi } \\
\text { - Persebaran PKL non } \\
\text { stabilisasi tiga hari } \\
\text { pengamatan }\end{array}$ & $\begin{array}{l}\text { Mengolah data dengan tabel untuk } \\
\text { jumlah PKL non stabilisasi dan grafik } \\
\text { untuk jenis dagangan PKL stabilisasi. } \\
\text { Kemudian memetakan persebaran PKL } \\
\text { non stabilisasi pada } 3 \text { hari pengamatan }\end{array}$ & $\begin{array}{l}\text { - Grafik jenis dagangan } \\
\text { PKL stabilisasi } \\
\text { - Peta persebaran PKL } \\
\text { non stabilisasi }\end{array}$ \\
\hline
\end{tabular}

Sumber : Penulis, 2017

2) Analisis volume kendaraan ruas jalan Menteri Supeno Surakarta

Analisis ini menggunakan standar nasional MKJI (1997), dengan menggunakan data hasil traffic counting sebagai input, berikut adalah tabel analisis volume kendaraan ruas jalan Menteri Supeno: 
Tabel 2. Analisis Volume Kendaraan Jalan Menteri Supeno ( Q )

\begin{tabular}{|c|c|c|c|c|c|c|c|c|c|c|}
\hline \multirow{3}{*}{ No } & \multirow{3}{*}{ Klasifikasi Kendaraan } & \multicolumn{4}{|c|}{$\begin{array}{c}\text { Jumlah } \\
\text { Kendaraan }\end{array}$} & \multirow{3}{*}{ EMP } & \multicolumn{4}{|c|}{ SMP } \\
\hline & & \multicolumn{2}{|c|}{$\begin{array}{c}\mathrm{Dg} \\
\mathrm{PKL}\end{array}$} & \multicolumn{2}{|c|}{$\begin{array}{r}\text { Tp } \\
\text { PKL }\end{array}$} & & \multicolumn{2}{|c|}{ Dg PKL } & \multicolumn{2}{|c|}{ Tp PKL } \\
\hline & & 1 & 2 & 3 & 4 & & 1 & 2 & 3 & 4 \\
\hline 1 & HV (truk dan bus) & & & & & 1,20 & & & & \\
\hline 2 & LV (mobil, mobil box dII) & & & & & 1,00 & & & & \\
\hline 3 & $\mathrm{MC}$ (motor) & & & & & 0,25 & & & & \\
\hline 4 & UM (sepeda, becak dII) & & & & & \multicolumn{5}{|c|}{ dianggap sebagai hambatan samping } \\
\hline \multicolumn{7}{|c|}{ Jumlah } & \multicolumn{4}{|c|}{$x$} \\
\hline
\end{tabular}

Sumber : Penulis, 2017

Keterangan:

Dgn PKL : ruas jalan Menteri Supeno dengan adanya PKL stabilisasi

Tp PKL : ruas jalan Menteri Supeno tanpa adanya PKL stabilisasi

1 : pertigaan JI. Menteri Supeno-J. A. Yani ke arah timur

2 : pertigaan Jl. Menteri Supeno-JI. K.S Tubun ke arah barat

3 : pertigaan JI. Menteri Supeno-JI. K.S Tubun ke arah ke arah timur

4 : pertigaan J. Menteri Supeno-DISHUBKOMINFO ke arah barat

3) Analisis parkir on street ruas jalan Menteri Supeno Surakarta

Analisis ini terdiri dari lima analisis, seluruhnya menggunakan statisitik deskriptif dengan menggunakan tabel dan grafik. Berikut adalah tabel analisis parkir on street :

Tabel 3. Analisis parkir on street ruas jalan Menteri Supeno Surakarta

\begin{tabular}{|c|c|c|c|c|c|c|}
\hline Hari & $\begin{array}{c}\text { Jenis } \\
\text { Kendaraan }\end{array}$ & $\begin{array}{c}\text { Volume } \\
\text { Parkir }\end{array}$ & $\begin{array}{l}\text { Akumulasi } \\
\text { Kendaraan }\end{array}$ & $\begin{array}{l}\text { Rata-rata } \\
\text { lama parkir }\end{array}$ & $\begin{array}{c}\text { Kapasitas } \\
\text { parkir }\end{array}$ & Indeks parkir \\
\hline \multirow{2}{*}{ Sabtu } & $\mathrm{MC}$ & & & & & \\
\hline & LV & & & & & \\
\hline \multirow{2}{*}{ Minggu } & $\mathrm{MC}$ & & & & & \\
\hline & LV & & & & & \\
\hline \multirow{2}{*}{ Senin } & $\mathrm{MC}$ & & & & & \\
\hline & LV & & & & & \\
\hline
\end{tabular}

Sumber : Penulis, 2017

Setelah nilai indeks parkir diperoleh kemudian disesuaikan dengan klasifikasi nilai indeks parkir pada tabel 4 :

Tabel 4. Klasifikasi nilai indeks parkir

\begin{tabular}{|c|l|}
\hline Nilai IP & \multicolumn{1}{|c|}{ Keterangan } \\
\hline$<1$ & Parkir tidak bermasalah, kebutuhan parkir tidak melebihi daya tampung \\
\hline$=1$ & Kebutuhan parkir seimbang dengan daya tampung \\
\hline$>1$ & Parkir bermasalah, kebutuhan parkir melebihi daya tampung \\
\hline
\end{tabular}

Sumber : Warpani, 1998

4) Analisis kapasitas jalan ruas jalan Menteri Supeno Surakarta

Pada analisis ini terbagi menjadi lima tahap, pada setiap tahap tersebut merupakan faktor penyesuaian komponen kapasitas jalan yang kemudian dihitung dengan rumus kapasitas jalan. Berikut adalah tabel analisis kapasitas jalan:

Tabel 5. Kapasitas Jalan Menteri Supeno (C)

\begin{tabular}{|l|l|c|c|}
\hline \multirow{2}{*}{ No } & \multicolumn{1}{|c|}{ Faktor Analisa } & \multicolumn{2}{|c|}{ NILAI } \\
\cline { 3 - 4 } & & Dgn PKL & Tp PKL \\
\hline 1 & Kapasitas Dasar (Co) (smp/jam) & $\mathrm{x}$ & $\mathrm{x}$ \\
\hline 2 & Faktor Penyesuaian Lebar Jalur (FCw) & $\mathrm{x}$ & $\mathrm{x}$ \\
\hline 3 & Faktor penyesuaian akibat pemisah arah (FCsp) & $\mathrm{x}$ & $\mathrm{x}$ \\
\hline 4 & Faktor Penyesuaian Hambatan Samping (FCsf) & $\mathrm{x}$ \\
\hline
\end{tabular}




\begin{tabular}{|l|l|l|l|}
\hline 5 & Faktor Penyesuaian Ukuran Kota ( FCcs) & $\mathbf{x}$ & $\mathrm{x}$ \\
\hline \multicolumn{2}{|c|}{ Kapasitas (C) = Co x FCw x FCSP x FCSF x FCCS (smp/jam) } & $\mathbf{x}$ & $\mathbf{x}$ \\
\hline
\end{tabular}

Keterangan :

Sumber: Penulis, 2017

Dgn PKL : ruas jalan Menteri Supeno dengan adanya PKL stabilisasi

Tp PKL : ruas jalan Menteri Supeno tanpa adanya PKL stabilisasi

5) Analisis kinerja jalan ruas jalan Menteri Supeno Surakarta

Dalam melakukan analisis, data terpilah menjadi dua yaitu data dari ruas jalan tanpa adanya PKL stabilisasi dan data ruas jalan dengan adanya PKL stabilisasi dengan menyajikan nilai kinerja jalan di masing-masing hari perhitungan (Senin, Sabtu dan Minggu) yang dihitung dengan menggunakan rumus DS. Berikut adalah rumus untuk menghitung besar derajat kejenuhan (MKJI, 1997).

Keterangan :

$$
D S=\frac{Q}{C}
$$

DS : degree of saturation (derajat kejenuhan)

Q : volume kendaraan per jam

C : Kapasitas jalan yang sebenarnya

Untuk mendapatkan nilai DS harus mengetahui nilai dari Q dan C. Berikut adalah klasifikasi nilai DS dan keteranganya.

Tabel 6. Klasifikasi Nilai DS pada Berbagai Kondisi

\begin{tabular}{|c|l|}
\hline Nilai DS & \multicolumn{1}{c|}{ Klasifikasi Kinerja Jalan } \\
\hline $0,1-0,7$ & Kondisi kinerja jalan baik, dimana kendaraan dapat berjalan lancar \\
\hline $0,7-0,8$ & Kondisi kinerja jalan baik, dimana kendaraan berjalan lancar dengan sedikit hambatan \\
\hline $0,8-0,9$ & $\begin{array}{l}\text { Kondisi kinerja jalan cukup baik, dimana kendaraan berjalan lancer tapi adanya hambatan } \\
\text { lalulintas sudah lebih mengganggu }\end{array}$ \\
\hline $0,9-1,0$ & Kondisi kinerja jalan kurang baik, dimana kendaraan berjalan dengan banyak hambatan \\
\hline$>1,0$ & $\begin{array}{l}\text { Kondisi kinerja jalan buruk, dimana kendaran berjalan sangat lamban dan cenderung macet, } \\
\text { banyak kendaraan akan berjalan pada bahu jalan }\end{array}$ \\
\hline
\end{tabular}

Sumber: MKJI, 1997

6) Analisis pengaruh PKL stabilisasi shelter Manahan terhadap kinerja Menteri Supeno Surakarta

Pada analisis ini, pengaruh diperoleh dengan mengaitkan hasil analisis aktifitas PKL stabilisasi dengan volume kendaraan kemudian dengan kinerja jalan. Selanjutnya mengaitkan hasil analisis parkir on street dengan kapasitas jalan kemudian dengan kinerja jalan. Kedua pengaitan tersebut kemudian di hitung secara statistik yang meliputi volume, kapasitas dan kinerja jalan dengan membagi ruas jalan dengan dan tanpa PKL stabilisasi seperti tabel berikut ini :

Tabel 7. Contoh Tabel Pengaruh Stabilisasi terhadap Kinerja Jalan

\begin{tabular}{|c|c|c|c|c|c|c|c|c|c|c|c|c|c|c|c|c|c|c|}
\hline \multirow[b]{2}{*}{ Variabel } & \multicolumn{8}{|c|}{ Volume Kendaraan (V) } & \multicolumn{2}{|c|}{ Kapasitas Jalan } & \multicolumn{8}{|c|}{ Kinerja jalan (V/C) } \\
\hline & \multicolumn{4}{|c|}{ Dgn PKL } & \multicolumn{4}{|c|}{ Tp PKL } & $\begin{array}{l}\text { Dgn } \\
\text { PKL }\end{array}$ & Tp PKL & \multicolumn{4}{|c|}{ Dgn PKL } & \multicolumn{4}{|c|}{ Tp PKL } \\
\hline \multicolumn{19}{|c|}{ Waktu Pelayanan } \\
\hline \multicolumn{19}{|l|}{ Skala Pelayanan } \\
\hline \multicolumn{19}{|c|}{ Pola Sebaran } \\
\hline \multicolumn{19}{|l|}{ Homogenitas } \\
\hline \multicolumn{19}{|l|}{ Indeks Parkir } \\
\hline \multirow{4}{*}{ Waktu } & \multicolumn{8}{|c|}{ Volume Kendaraan (V) } & \multicolumn{2}{|c|}{ Kapasitas Jalan } & \multicolumn{8}{|c|}{ Kinerja jalan (V/C) } \\
\hline & \multicolumn{4}{|c|}{ Dgn PKL } & \multicolumn{4}{|c|}{ Tp PKL } & \multirow{3}{*}{ Dgn PKL } & \multirow{3}{*}{$\begin{array}{c}\text { Tp } \\
\text { PKL }\end{array}$} & \multicolumn{4}{|c|}{ Dgn PKL } & \multicolumn{4}{|c|}{ Tp PKL } \\
\hline & \multicolumn{2}{|c|}{ A } & \multicolumn{2}{|c|}{ B } & \multicolumn{2}{|c|}{ C } & \multicolumn{2}{|c|}{ D } & & & \multicolumn{2}{|c|}{ A } & \multicolumn{2}{|c|}{ B } & \multicolumn{2}{|c|}{ C } & \multicolumn{2}{|c|}{ D } \\
\hline & $\mathrm{rr}$ & $t$ & $\mathrm{rr}$ & $t$ & $\mathrm{rr}$ & $\mathrm{t}$ & $\mathrm{rr}$ & $t$ & & & $\mathrm{rr}$ & $t$ & $\mathrm{rr}$ & $t$ & $\mathrm{rr}$ & $\mathrm{t}$ & $\mathrm{rr}$ & $\mathrm{t}$ \\
\hline Pagi & & & & & & & & & & & & & & & & & & \\
\hline Siang & & & & & & & & & & & & & & & & & & \\
\hline Sore & & & & & & & & & & & & & & & & & & \\
\hline
\end{tabular}

Sumber : Penulis, 2017 


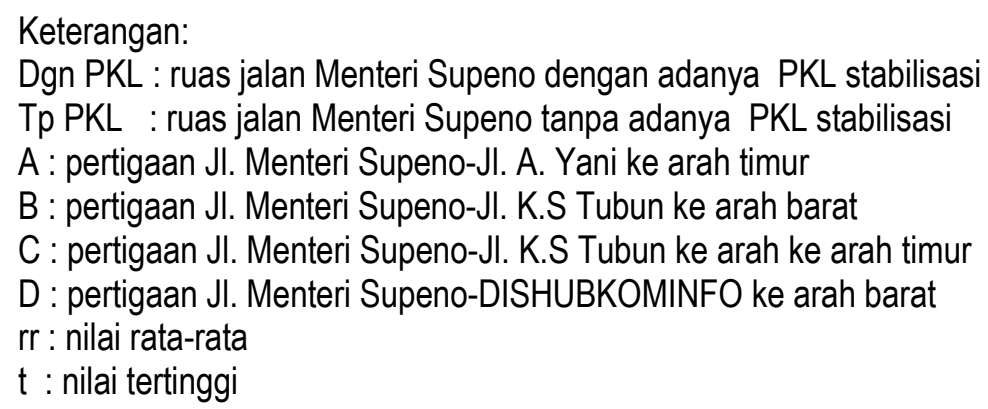

\section{HASIL DAN PEMBAHASAN}

Berdasarkan tujuan penelitian yaitu mengetahui pengaruh stabilisasi PKL shelter Manahan terhadap kinerja jalan Menteri Supeno, diperoleh empat sasaran untuk menjawab tujuan penelitian yaitu analisis aktifitas PKL stabilisasi pemicu bangkitan pergerakan dilanjutkan analisis volume kendaraan jalan Menteri Supeno, analisis kondisi parkir on street yang dilanjutkan analisis kapasitas jalan Menteri Supeno, analisis kinerja jalan Menteri Supeno dan analisis pengaruh stabilisasi PKL shelter Manahan terhadap kinerja jalan Menteri Supeno. Berikut adalah masing-masing pembahasan sasaran tersebut.

1) Analisis aktifitas PKL shelter Manahan sebagai pemicu bangkitan pergerakan

Pada analisis ini terdiri dari empat komponen, diantaranya; waktu pelayanan, skala pelayanan, pola sebaran memanjang dan homogenitas jenis dagangan. Keempat komponen tersebut menghasilkan potensi bangkitan pergerakan menuju ruas jalan Menteri Supeno yang merupakan lokasi PKL stabilisasi. Berikut adalah masing-masing hasil dari keempat komponen di atas :

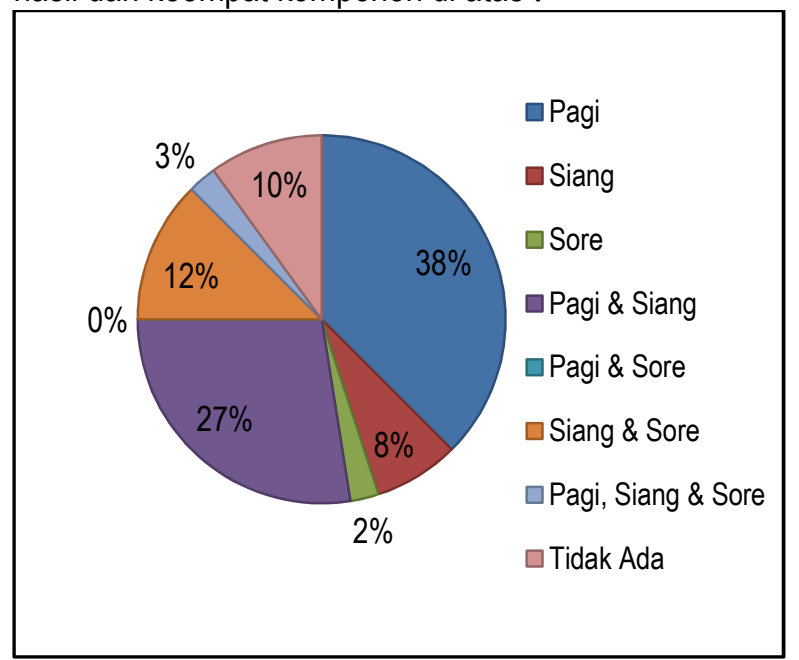

Sumber. Analisis Penulis, 2017

Gambar 1. Presentase peak time PKL stabilisasi

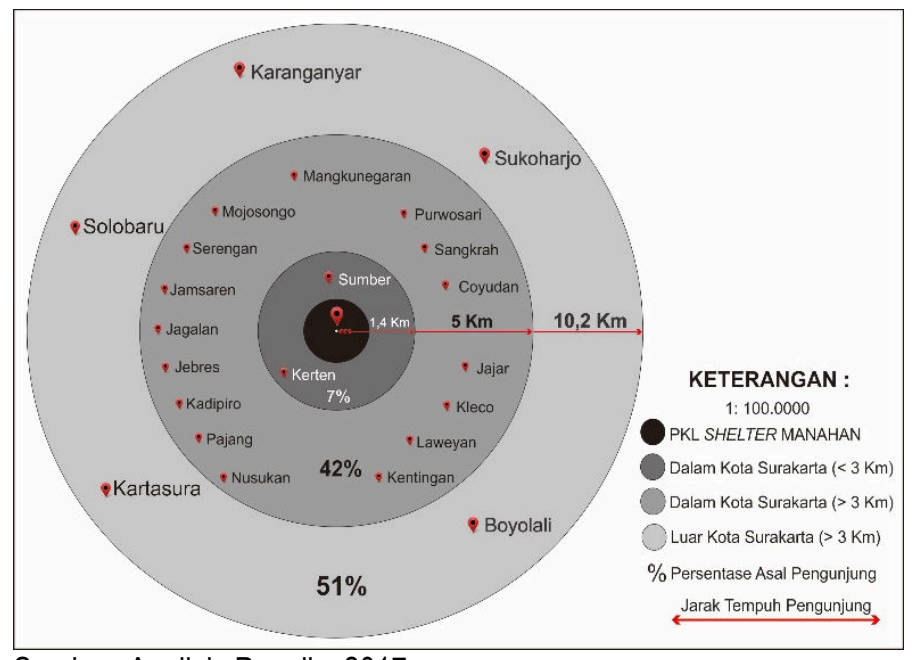

Sumber. Analisis Penulis, 2017

Gambar 2. Skala pelayanan PKL stabilisasi

PKL stabilisasi memiliki waktu pelayanan mulai dari 07.00-17.00 WIB. Berdasarkan hasil survei diperoleh klasifikasi rentang waktu puncak pelayanan adalah jam $7-8$ pagi, 12 - 1 siang dan $4-5$ sore. Gambar 1. diperoleh hasil bahwa rentang waktu ramai pengunjung adalah pagi hari. Adanya kondisi diatas sesuai dengan pendapat Haryanti (2008), menjelaskan bahwa PKL umumnya memiliki rentang waktu puncak pada saat berangkat kerja (07.00-08.00 WIB), istirahat (12.00-13.00 WIB) dan pulang kerja (16.00-17.00 WIB). Selain itu, adanya rentang waktu puncak PKL mengindikasi terjadinya potensi peningkatan pergerakan, karena banyak pengunjung yang mengakses PKL pada waktu puncak, sehingga, bisa dikatakan bahwa pada rentang waktu pagi hari berpotensi terjadi bangkitan pergerakan yang besar di Jl. Menteri Supeno.

Pada gambar 2. PKL stabilisasi memiliki jangkauan pelayanan lebih dari $3 \mathrm{~km}$. Pada komponen skala pelayanan terbagi menjadi tiga klasifikasi yaitu dari dalam kota Surakarta $(<3 \mathrm{Km})$, dalam kota Surakarta $(>3 \mathrm{Km})$, dan luar kota Surakarta $(>3 \mathrm{Km}$ ). Sebesar $93 \%$ pengunjung menempuh jarak lebih dari $3 \mathrm{~km}$ yang seluruhnya memiliki tujuan pergerakan PKL stabilisasi Manahan. Kondisi di atas sesuai dengan pendapat Haryanti (2008), menjelaskan bahwa PKL memiliki skala pelayanan luas jika menempuh jarak lebih dari $3 \mathrm{~km}$. Luasnya skala pelayanan PKL dapat berindikasi pada besarnya tarikan pergerakan menuju lokasi dagang PKL, sehingga berpotensi pada peningkatan pergerakan. 


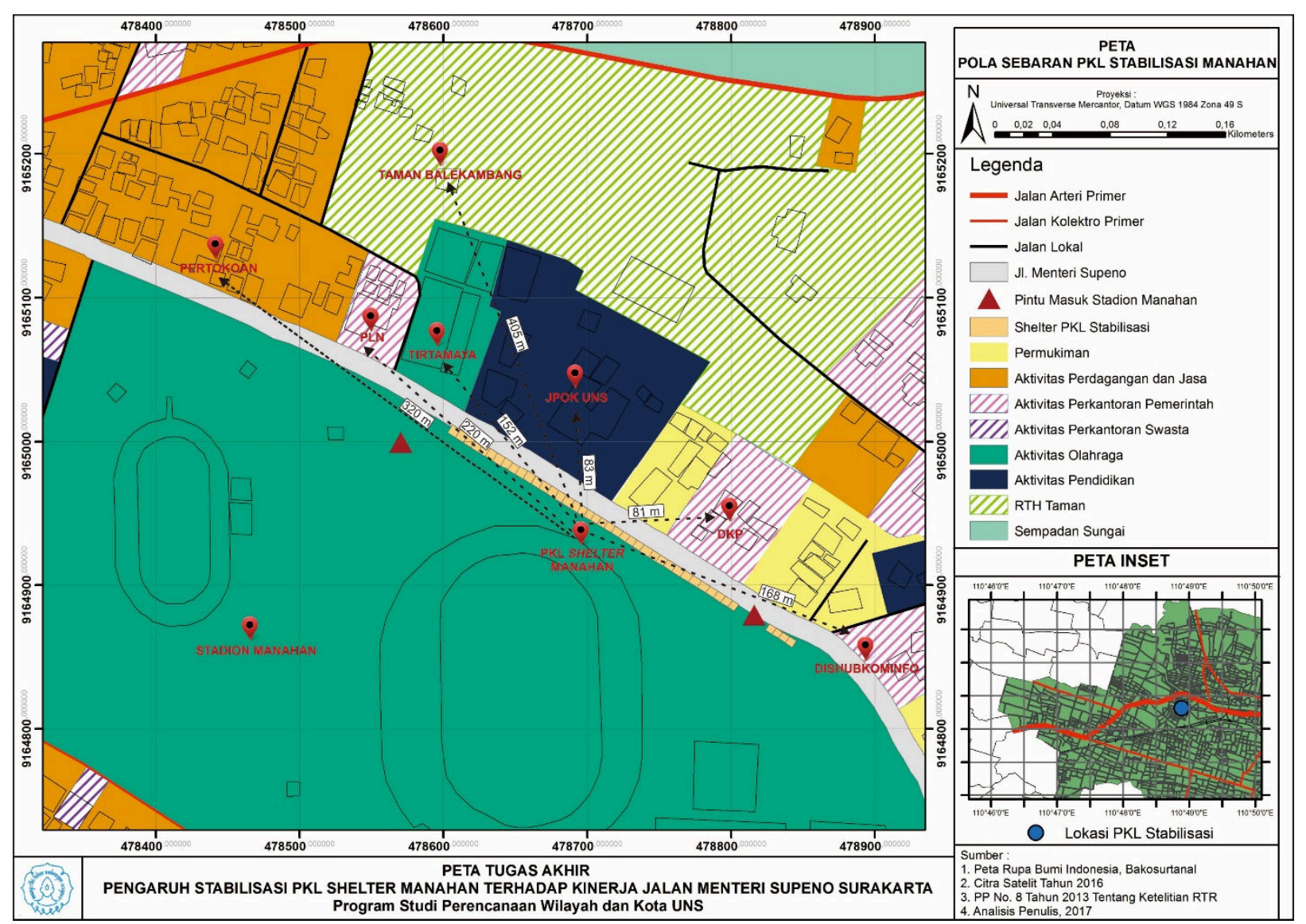

Sumber. Analisis Penulis, 2017

Gambar 3. Peta Sebaran PKL stabilisasii shelter Manahan terhadap Keberadaan Aktivitas di Sekitarnya

Pada gambar 3. PKL stabilisasi Manahan memiliki pola keruangan yang berbentuk linier dengan mengikuti jaringan jalan Menteri Supeno. Keberadaan PKL stabilisasi Manahan di tepi jalan Menteri Supeno berada sangat dekat dengan pusatpusat aktivitas yang ada di sekitar lokasi dagang PKL stabilisasi. Sebanyak delapan pusat aktivitas tersebar di sekitar PKL stabilisasi Manahan dengan rata-rata jarak kedekatan sejauh $179 \mathrm{~m}$ dengan jarak terdekat adalah stadion Manahan sejauh $0 \mathrm{~m}$. Selain melayani orang-orang yang melakukan aktivitas di pusat-pusat aktivitas yang ada, agar PKL stabilisasi mudah diakses oleh pengunjung dari luar kawasan mengingat letaknya berada di pinggir jalan. Adanya kondisi tersebut sesuai dengan pendapat Mc. Gee dan Yeung (1977), salah satu karakteristik berlokasi PKL adalah mengikuti jaringan jalan. Bentuk perserbaran dengan mengikuti pola jaringan jalan ini bertujuan untuk memudahkan pengunjung untuk mengakses PKL. Selain itu, karakter berlokasi PKL memilih kawasan dengan variasi aktivitas yang banyak seperti halnya di kawasan Manahan yang memiliki delapan pusat aktivitas. Sehingga keberadaan PKL stabilisasi dan pusat-pusat aktivitas sekitarnya akan memperkuat daya tarik kawasan yang berujung pada akumulasi pergerakan lalulintas menuju Jl. Menteri Supeno Surakarta.

PKL stabilisasi Manahan tergolong homogen, karena 95\% PKL stabilisasi menjual makanan dan minuman. Aglomerasi PKL stabilisasi menghasilkan suatu hubungan yang saling menguntungkan, selain itu, kesamaan jenis dagangan PKL stabilisasi yang teraglomerasi di Jl. Menteri Supeno menjadi daya tarik bagi PKL baru/non stabilisasi untuk membuka lapak dagang di sekitar lokasi dagang PKL stabilisasi. Jika dilihat pada gambar 4. pada tiga hari perhitungan, jumlah PKL baru berbeda-beda pada setiap harinya. Jumlah PKL baru paling banyak adalah hari Minggu, persebaran PKL baru mengumpul di depan gerbang masuk stadion Manahan dan sebagian lagi menjalar di sepanjang Jl. Menteri Supeno. Jika disesuaikan dengan teori, kondisi diatas sesuai dengan pendapat Mc. Gee dan Yeung (1977) bahwa PKL akan memilih berdagang mendekati sekumpulan PKL sejenis yang beraglomerasi pada suatu kawasan. Selain itu menurut Roever (2014), keberadaan PKL baru cenderung menempati tempat umum seperti bahu jalan, trotoar, pintu masuk (pasar, stadion dll) dan pedestrian.Edward (2010), Aglomerasi merupakan sebuah keuntungan yang diperoleh ketika sejumlah tempat usaha bidang sejenis membentuk cluster di suatu kawasan dan menjadi satu aktivitas yang baru. Adanya pusat aktivitas akan menimbulkan tarikan pergerakan pada kawasan tersebut. 


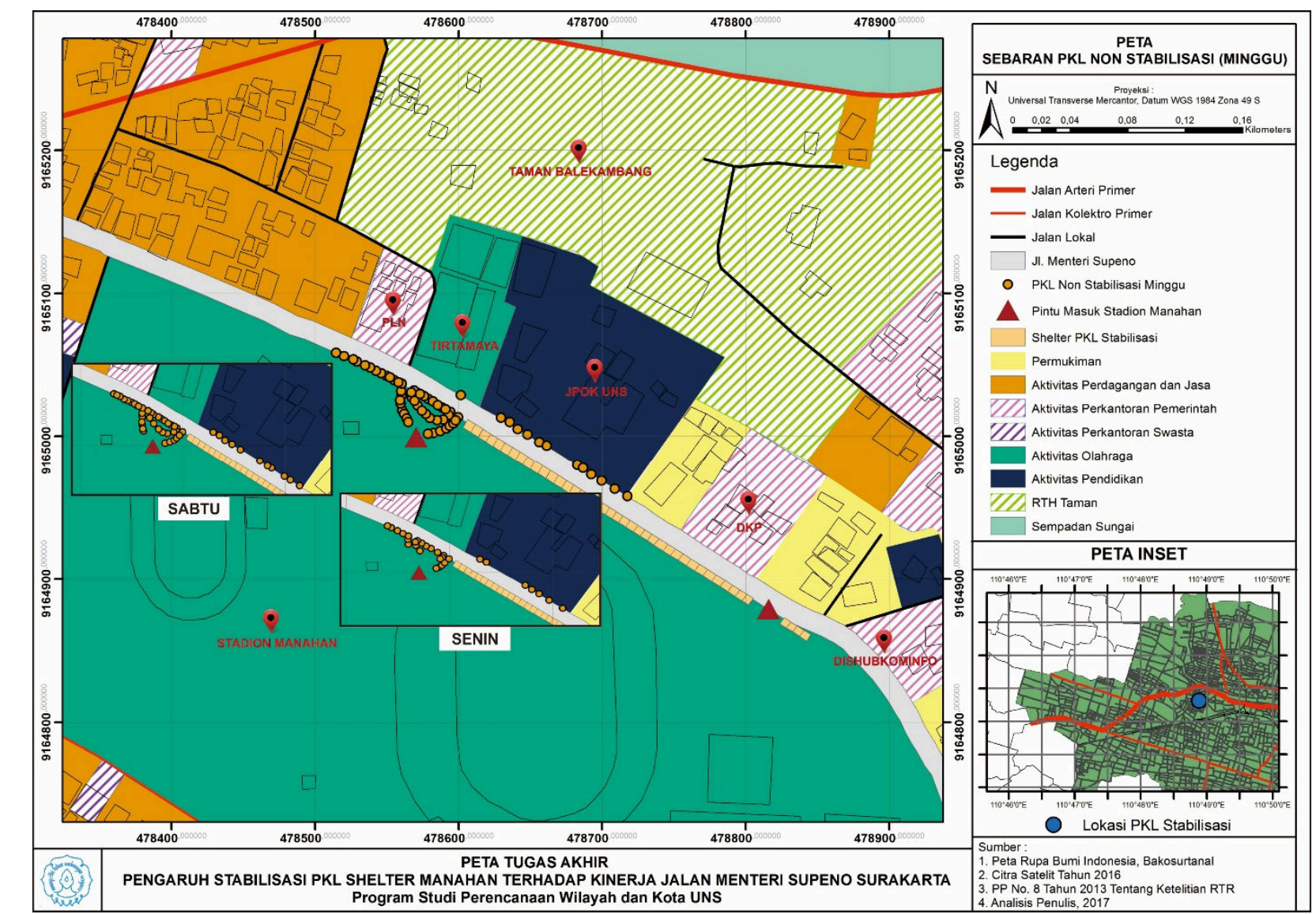

Sumber. Analisis Penulis, 2017

Gambar 4. Peta Sebaran PKL Non stabilisasi shelter Manahan pada Kurun Waktu yang Berbeda

- Analisis volume kendaraan jalan Menteri Supeno

Mataram (2011), besar kecilnya bangkitan pergerakan pada suatu kawasan diketahui dengan menghitung volume kendaraan yang melalui ruas jalan di suatu kawasan. Dari analisis sebelumnya telah disebutkan bahwa ada potensi peningatan bangkitan pergerakan, sehingga jika dikaitkan dengan teori Mataram maka volume yang akan dihasilkan juga akan meningkat. Dalam menghitung volume kendaraan, ruas jalan Menteri Supeno dibagi menjadi dua penggal yaitu penggal jalan dengan PKL stabilisasi dan tanpa PKL stabilisasi. Berikut adalah perhitungannya :

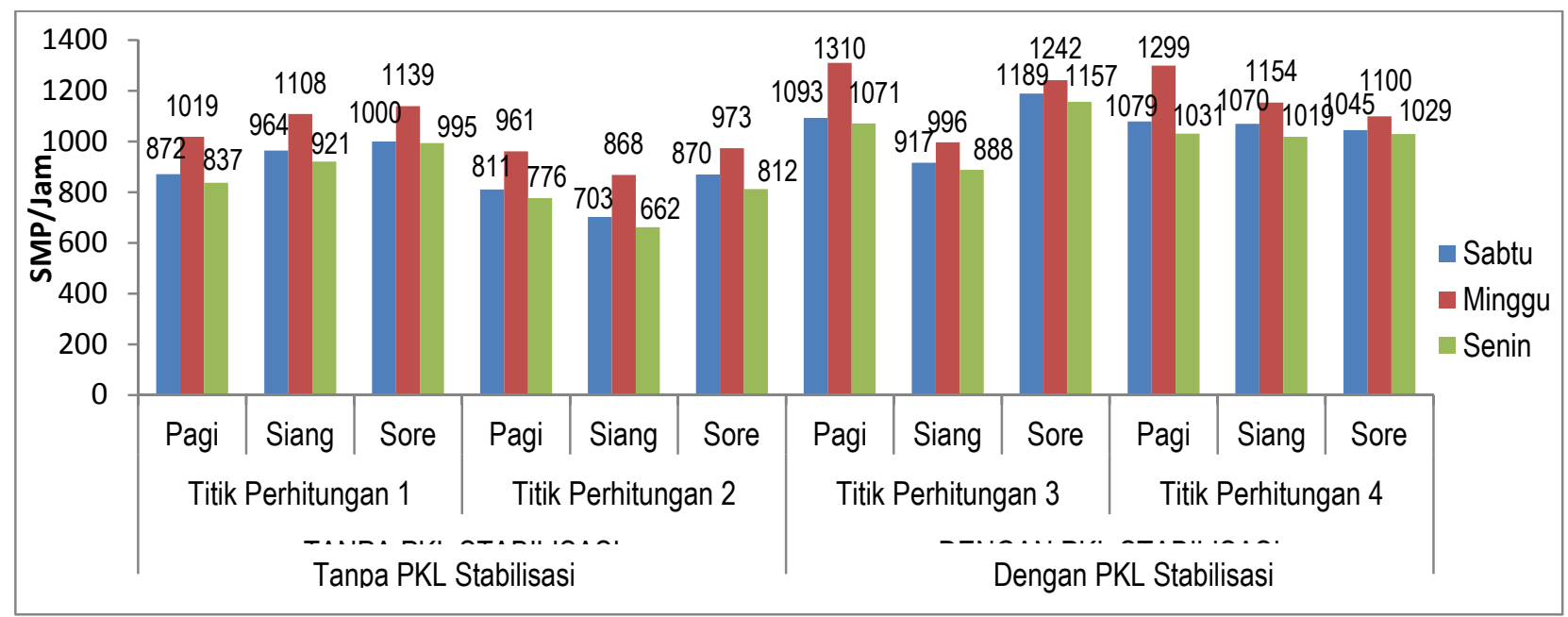

Sumber. Analisis Penulis, 2017

Gambar 5. Volume Kendaraan Jl. Menteri Supeno Surakarta 
Berdasarkan gambar 5. diperoleh hasil bahwa volume kendaraan pada kedua penggal jalan memiliki perbedaan, volume kendaraan pada penggal jalan dengan PKL lebih besar dari pada penggal jalan tanpa PKL. Selain itu, volume kendaraan di ruas jalan Menteri Supeno berada pada puncaknya di hari Minggu karena terdapat pusat aktivitas perdagangan tambahan berupa Sunday Market di Stadion Manahan. Adanya hasil analisis ini sesuai dengan pendapat Tamin (2000), besarnya lalulintas tergantung pada jenis aktivitas yang ada, jenis aktivitas perdagangan menghasilkan arus yang lebih besar dari pada jenis aktivitas lainnya. Sehingga, dapat dipastikan bahwa penggal jalan Menteri Supeno dengan PKL stabilisasi menarik pergerakan lebih besar dibandingkan dengan penggal jalan tanpa PKL stabilisasi.

\section{2) Analisis parkir on street jalan Menteri Supeno}

Pada analisis parkir on street ruas jalan Menteri Supeno, terdiri dari lima komponen meliputi; volume pakir, akumulasi parkir, rata-rata lama parkir, kapasitas parkir dan indeks parkir. Kelima komponen tersebut bertujuan untuk mengetahui kondisi parkir on street yang ada di ruas jalan Menteri Supeno. Indeks parkir merupakan analisis penentu bagaimana kondisi parkir on street ruas jalan Menteri Supeno bermasalah atau tidak.

Tabel 8. Komponen parkir on street JI. Menteri Supeno

\begin{tabular}{|c|c|c|c|c|c|c|c|}
\hline \multirow{2}{*}{ Hari } & $\begin{array}{c}\text { Jenis } \\
\text { kendaraan }\end{array}$ & $\begin{array}{c}\text { Volume } \\
\text { Parkir }\end{array}$ & $\begin{array}{c}\text { Akumulasi Parkir } \\
(\mathbf{0 7 . 0 0}-\mathbf{0 8 . 0 0} \text { WIB) }\end{array}$ & $\begin{array}{c}\text { Jumlah Slot } \\
\text { Parkir (S) }\end{array}$ & $\begin{array}{c}\text { Durasi } \\
\text { parkir (D) }\end{array}$ & $\begin{array}{c}\text { Kapasitas } \\
\text { Parkir (S/D) }\end{array}$ & $\begin{array}{c}\text { Indeks } \\
\text { Parkir }\end{array}$ \\
\hline \multirow{2}{*}{ Sabtu } & MC & 360 & 97 & 220 & 0,5 & 440 & 0,22 \\
\cline { 2 - 8 } & LV & 195 & 45 & 30 & 0,7 & 43 & 1,05 \\
\hline \multirow{2}{*}{ Minggu } & MC & 640 & 173 & 220 & 0,7 & 314 & 0,55 \\
\cline { 2 - 8 } & LV & 290 & 52 & 30 & 0,8 & 38 & 1,39 \\
\hline \multirow{2}{*}{ Senin } & MC & 236 & 75 & 220 & 0,4 & 550 & 0,14 \\
\cline { 2 - 8 } & LV & 155 & 28 & 30 & 0,5 & 60 & 0,47 \\
\hline
\end{tabular}

Sumber : Analisis penulis, 2017

Analisis parkir on street menghasilkan kondisi bahwa parkir mengalami masalah karena nilai indeks parkir sudah melebihi daya tampung. Selain itu besarnya gangguan yang dihasilkan oleh parkir ini salah satunya dapat dilihat dari besar volume parkir. Menurut MKJI (1997) dalam menentukan faktor penyesuaian hambatan samping (FCsf) pada analisis kapasitas jalan dapat dengan menghitung jumlah hambatan samping yang ada, jumlah kendaraan sebesar 930 kendaraan membuat jalan Menteri Supeno masuk pada kelas gangguan samping sangat tinggi.

\section{- Analisis kapasitas jalan Menteri Supeno}

Analisis parkir on street menghasilkan bahwa adanya fasilitas penunjang PKL stabilisasi yang berupa parkir on street di ruas jalan Menteri Supeno secara signifikan menurunkan kapasitas jalan. Kondisi tersebut sudah sesuai dengan pendapat Wahyuni (2008), adanya parkir di pinggir jalan merupakan salah satu permasalah, karena secara signifikan menurunkan nilai kapasitas jalan. Dalam menghitung kapasitas jalan Menteri Supeno dibagi menjadi dua penggal yaitu penggal jalan dengan PKL stabilisasi dan tanpa PKL stabilisasi. Berikut adalah perhitungannya :

Tabel 9. Perhitungan Kapasitas Jalan Menteri Supeno

\begin{tabular}{|c|l|c|c|}
\hline \multirow{2}{*}{ No } & \multicolumn{1}{|c|}{ Faktor Analisis } & \multicolumn{2}{c|}{ Nilai } \\
\cline { 3 - 3 } & \multicolumn{1}{|c|}{ Dg PKL } & Tp PKL \\
\hline 1 & Kapasitas Dasar (Co) (smp/jam) & 2900 & 2900 \\
\hline 2 & Faktor Penyesuaian Lebar Jalur (FCw) & 0,56 & 1 \\
\hline 3 & Faktor penyesuaian akibat pemisah arah (FCsp) & 0,97 & 1 \\
\hline 4 & Faktor Penyesuaian Hambatan Samping (FCsf) & 0,91 & 0,95 \\
\hline 5 & Faktor Penyesuaian Ukuran Kota ( FCcs) & 0,94 & 0,94 \\
\hline \multicolumn{2}{|l}{ Kapasitas (C) = Co x FCw x FCSP x FCSF x FCCS (smp/jam) } & 1347 & 2590 \\
\hline
\end{tabular}

Keterangan :

Dgn PKL : ruas jalan Menteri Supeno dengan adanya PKL stabilisasi

Tp PKL : ruas jalan Menteri Supeno tanpa adanya PKL stabilisasi 
Berdasarkan pada tabel 9. dihasilkan bahwa kapasitas jalan Menteri Supeno memiliki perbedaan yang cukup signifikan pada kedua penggal jalan yang ada. Kedua penggal jalan memiliki kecenderungan yang berbeda pada kelima faktor penyesuaian tersebut hingga dihasilkan nilai yang telah disebutkan di atas. Salah satu hal yang menyebabkan perbedaan yang cukup signifikan antara kedua penggal jalan Menteri Supeno adalah adanya fasilitas parkir on street PKL stabilisasi di penggal jalan dengan PKL. Kondisi ini telah sesuai dengan teori dari Wahyuni (2008) bahwa adanya parkir di pinggir jalan merupakan salah satu permasalah, karena secara signifikan menurunkan nilai kapasitas jalan.

3) Analisis kinerja jalan Menteri Supeno

MKJI (1997), Kinerja jalan diperoleh melalui perbandingan antara volume kendaraan terhadap kapasitas jalan. Berdasarkan volume kendaraan dan kapasitas jalan dari kedua penggal jalan Menteri Supeno yang telah diperoleh sebelumnya, berikut adalah hasil perhitungan kinerja jalan dari kedua penggal jalan yang ada.

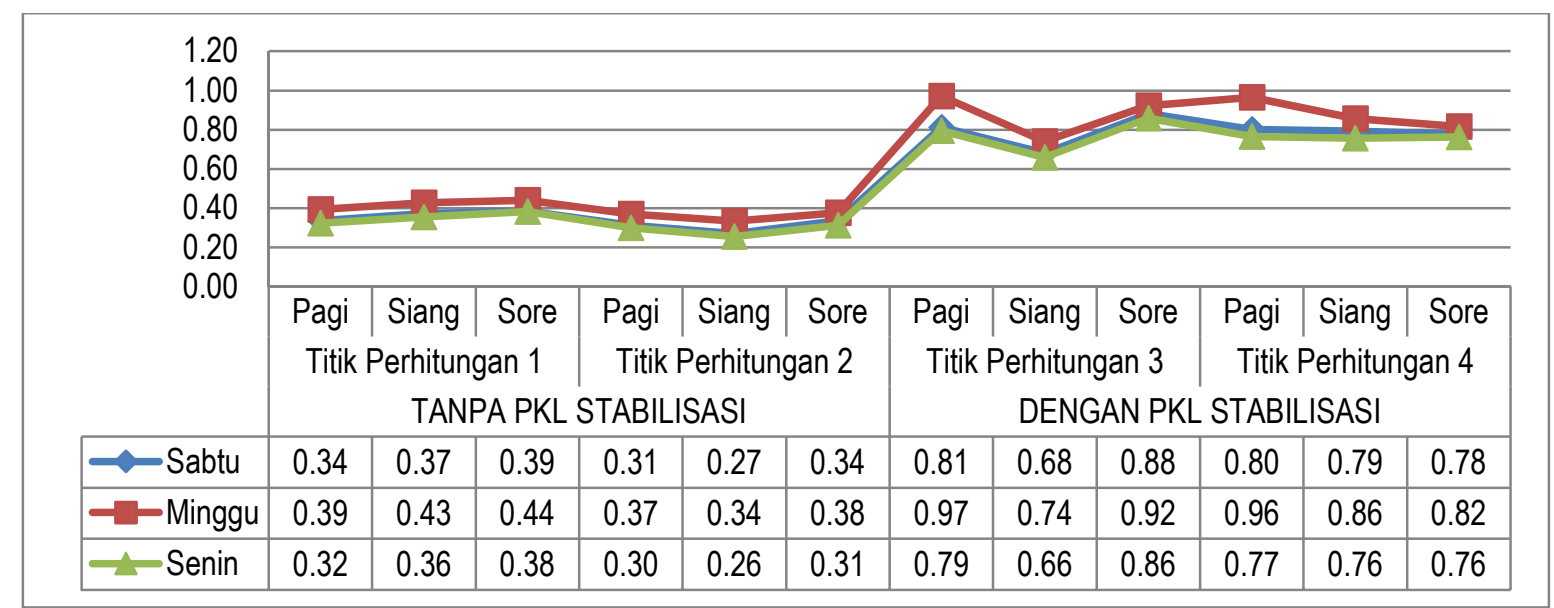

Sumber. Analisis Penulis, 2017

Gambar 6. Kinerja jalan Menteri Supeno Surakarta

Pada gambar 6. diperoleh hasil bahwa kinerja jalan pada penggal jalan tanpa PKL stabilisasi masih pada kondisi aman yaitu jalan pada kondisi baik, namun pada penggal jalan dengan PKL stabilisasi kondisi kinerja jalan mengalami gangguan yang bervariasi mulai dari gangguan ringan hingga gangguan berat (jalan berjalan dengan banyak hambatan). Analisis ini telah disesuaikan dengan ketentuan nasional dari MKJI (1997) bahwa setiap nilai derajat kejenuhan memiliki kondisi kinerja jalan yang berbeda-beda. Nilai derajat kejenuhan tertinggi yaitu pada rentang 0,9 1,0 dengan kondisi kinerja jalan kurang baik, kendaraan berjalan dengan banyak hambatan. Sehingga disimpulkan bahwa penggal jalan Menteri Supeno dengan PKL stabilisasi mengalami penurunan kinerja jalan.

4) Analisis pengaruh stabilisasi PKL shelter Manahan terhadap kinerja jalan Menteri Supeno

Dalam mengetahui pengaruh yang terjadi, penulis akan membandingan antara penggal jalan Menteri Supeno dengan PKL stabilisasi terhadap penggal jalan tanpa PKL stabilisasi. Saat melakukan analisis, penulis akan menyesuaikan data yang meliputi: aktivitas PKL stabilisasi, indeks parkir, volume kendaraan, kapasitas jalan dan kinerja jalan. Hal ini bertujuan untuk mengetahui kecenderungan yang terjadi pada variabel-variabel tersebut yang kemudian diukur secara statistik besar pengaruh yang terjadi pada kedua penggal jalan tersebut dengan perhitungan volume kendaraan, kapasitas jalan dan kinerja jalan. Berikut adalah Tabel pengaruh stabilisasi PKL terhadap kinerja jalan Menteri Supeno : 
Tabel 10. Pengaruh stabilisasi PKL shelter Manahan terhadap kinerja jalan Menteri Supeno Sumber: Analisis Penulis

\begin{tabular}{|c|c|c|c|c|c|c|c|c|c|c|c|c|c|c|c|c|c|c|}
\hline \multirow{2}{*}{ Variabel } & \multicolumn{6}{|c|}{ Volume Kendaraan (V) JI. Menteri Supeno } & \multicolumn{6}{|c|}{ Kapasitas Jalan (C) Jl. Menteri Supeno } & \multicolumn{6}{|c|}{ Kinerja jalan (V/C) JI. Menteri Supeno } \\
\hline & \multicolumn{2}{|c|}{ Tanpa PKL } & \multicolumn{4}{|c|}{ Dengan PKL } & \multicolumn{2}{|c|}{ Tanpa PKL } & \multicolumn{4}{|c|}{$\begin{array}{c}\text { Dengan PKL } \\
\end{array}$} & \multicolumn{2}{|c|}{ Tanpa PKL } & \\
\hline $\begin{array}{c}\text { Waktu } \\
\text { Pelayanan }\end{array}$ & \multirow{4}{*}{\multicolumn{2}{|c|}{$\begin{array}{l}\text { Tidak ada } \\
\text { pengaruh } \mathrm{PKL} \\
\text { stabilisasi } \\
\text { pada penggal } \\
\text { jalan ini }\end{array}$}} & \multicolumn{4}{|c|}{$\begin{array}{l}\text { Peak time terjadi pagi hari, menyebabkan } \\
\text { terjadinya bangkitan pergerakan tinggi di pagi } \\
\text { hari sehingga berpengaruh terhadap volume } \\
\text { kendaraan yang meningkat di pagi }\end{array}$} & & & & & & & \multirow{4}{*}{\multicolumn{2}{|c|}{$\begin{array}{l}\text { Tidak ada } \\
\text { pengaruh } \\
\text { PKL } \\
\text { stabilisasi } \\
\text { pada penggal } \\
\text { jalan ini }\end{array}$}} & \multirow{4}{*}{\multicolumn{4}{|c|}{$\begin{array}{l}\text { Adanya bangkitan pergerakan } \\
\text { yang disebabkan oleh aktivitas } \\
\text { PKL stabilisasi meningkatkan } \\
\text { volume kendaraan Jl. Menteri } \\
\text { Supeno. Sehingga, } \\
\text { kecenderungan ini } \\
\text { mengakibatkan nilai V besar } \\
\text { yang mempengaruhi nilai } \\
\text { kinerja jalan. Semakin besar } \\
\text { nilai V semakin rendah nilai } \\
\text { kinerja jalan. }\end{array}$}} \\
\hline $\begin{array}{c}\text { Skala } \\
\text { Pelayanan }\end{array}$ & & & \multirow{2}{*}{\multicolumn{4}{|c|}{$\begin{array}{l}\text { Skala pelayanan PKL stabilisasi luas, } 93 \% \\
\text { pelanggan menempuh jarak }>3 \mathrm{Km} \text {. Hal ini } \\
\text { mempengaruhi volume pergerakan } \\
\text { Mengikuti pola jalan, dekat dengan pusat } \\
\text { aktivitas sekitar yang menyebabkan volume } \\
\text { meningkat akibat imbas tarikan pergerakan. }\end{array}$}} & & & & & & & & & & & & \\
\hline Pola Sebaran & & & & & & & & & & & & & & & & & & \\
\hline Homogenitas & & & \multicolumn{4}{|c|}{$\begin{array}{l}\text { PKL stabilisasi homogen dan teraglomerasi } \\
\text { menjadi satu pusat aktivitas baru. Adanya } \\
\text { pusat aktivitas memiliki kecenderungan } \\
\text { membangkitkan pergerakan yang } \\
\text { berpengaruh terhadap volume kendaraan }\end{array}$} & & & & & & & & & & & & \\
\hline $\begin{array}{l}\text { Indeks Parkir } \\
\text { (IP) }\end{array}$ & & & & & & & $\begin{array}{r}\text { Tida } \\
\text { pen } \\
\text { park } \\
\text { street } \\
\text { pengg } \\
\text { i }\end{array}$ & $\begin{array}{l}\text { ada } \\
\text { aruh } \\
\text { ron } \\
\text { pada } \\
\text { I jalan }\end{array}$ & $\begin{array}{l}\text { Nilai IP > } \\
\text { parkir ke } \\
\text { sehingga } \\
\text { berkuran } \\
\text { melebihi } \\
\text { menyeba }\end{array}$ & $\begin{array}{l}\text { di hari sabt } \\
\text { bangan day } \\
\text { bar efektif } \\
\text { kibat park } \\
\text { ri kapasita } \\
\text { an kapasit }\end{array}$ & $\begin{array}{l}\text { dan mir } \\
\text { tampun } \\
\text { Mente } \\
\text { on stree } \\
\text { ya yan } \\
\text { jalan n }\end{array}$ & $\begin{array}{l}\text { u, } \\
\text { upeno } \\
\text { ang } \\
\text { urun }\end{array}$ & $\begin{array}{l}\text { Tidal } \\
\text { peng } \\
\text { parki } \\
\text { stree } \\
\text { peng } \\
\text { ini }\end{array}$ & $\begin{array}{l}\text { ada } \\
\text { uh } \\
\text { on } \\
\text { pada } \\
\text { al jalan }\end{array}$ & $\begin{array}{l}\text { Parkir } \\
\text { signifi } \\
\text { terhac } \\
\text { jalan, } \\
\text { yang } \\
\text { menu } \\
\text { Mente }\end{array}$ & $\begin{array}{l}n \text { street } \\
\text { n berpe } \\
\text { o penuru } \\
\text { hingga } \\
\text { dah dar } \\
\text { nkan kin } \\
\text { Supeno }\end{array}$ & $\begin{array}{l}\text { cara } \\
\text { aruh } \\
\text { an kape } \\
\text { ai kapa } \\
\text { t } \\
\text { ja jalan }\end{array}$ & $\begin{array}{l}\text { Isitas } \\
\text { sitas } \\
\text { S } \\
\end{array}$ \\
\hline \multirow{4}{*}{ Waktu } & \multicolumn{8}{|c|}{ Volume Kendaraan (smp/jam) JI. Menteri Supeno } & $\begin{array}{r}\text { Kapas } \\
\text { (sm } \\
\text { Jl. Ment }\end{array}$ & $\begin{array}{l}\text { s Jalan } \\
\text { Jam) } \\
\text { Supeno }\end{array}$ & \multicolumn{8}{|c|}{ Kinerja jalan (V/C) JI. Menteri Supeno } \\
\hline & \multicolumn{4}{|c|}{ Tanpa PKL } & \multicolumn{4}{|c|}{ Dengan PKL } & \multirow{3}{*}{$\begin{array}{l}\text { Tanpa } \\
\text { PKL }\end{array}$} & \multirow{3}{*}{$\begin{array}{l}\text { Dengan } \\
\text { PKL }\end{array}$} & \multicolumn{4}{|c|}{ Tanpa PKL } & \multicolumn{4}{|c|}{ Dengan PKL } \\
\hline & \multicolumn{2}{|c|}{$\begin{array}{c}\text { Titik } \\
\text { Perhitungan } \\
1\end{array}$} & \multicolumn{2}{|c|}{$\begin{array}{c}\text { Titik } \\
\text { Perhitungan } \\
2\end{array}$} & \multicolumn{2}{|c|}{$\begin{array}{c}\text { Titik } \\
\text { Perhitungan } \\
3\end{array}$} & \multicolumn{2}{|c|}{$\begin{array}{c}\text { Titik } \\
\text { Perhitungan } \\
4\end{array}$} & & & \multicolumn{2}{|c|}{$\begin{array}{l}\text { Titik } \\
\text { Perhitungan } \\
1\end{array}$} & \multicolumn{2}{|c|}{$\begin{array}{c}\text { Titik } \\
\text { Perhitunga } \\
\text { n } 2\end{array}$} & Perh & $\begin{array}{l}\text { ik } \\
\text { ungan }\end{array}$ & $\begin{array}{r}\mathrm{Ti} \\
\text { Perhi } \\
\text { i }\end{array}$ & tunga \\
\hline & $\mathrm{rr}$ & $t$ & $\mathrm{rr}$ & $\mathrm{t}$ & $\mathrm{rr}$ & $t$ & $\mathrm{rr}$ & $t$ & & & $\mathrm{rr}$ & $\mathrm{t}$ & $\mathrm{rr}$ & $\mathrm{t}$ & $\mathrm{rr}$ & $\mathrm{t}$ & $\mathrm{rr}$ & $t$ \\
\hline Pagi & 909 & 1019 & 849 & 961 & 1158 & 1310 & 1136 & 1299 & & & 0,35 & 0,39 & 0,33 & 0,37 & 0,86 & 0,97 & 0,84 & 0,96 \\
\hline Siang & 998 & 1108 & 744 & 868 & 934 & 996 & 1081 & 1154 & 2590 & 1347 & 0,39 & 0,43 & 0,29 & 0,34 & 0,69 & 0,74 & 0,80 & 0,86 \\
\hline Sore & 1045 & 1139 & 885 & 973 & 1196 & 1242 & 1058 & 110 & & & 0,40 & 0,44 & 0,34 & 0,38 & 0,89 & 0,92 & 0,79 & 0,82 \\
\hline
\end{tabular}


Dari penjelasan tabel 10. pengaruh stabilisasi PKL stabilisasi Manahan terhadap kinerja jalan terjadi karena dimulai oleh variabel-variabel aktivitas PKL stabilisasi membangkitkan pergerakan kemudian variabel parkir on street yang mengalami kekurangan daya tampung secara signifikan menurunkan kapasitas jalan menyebabkan kemampuan jalan Menteri Supeno dalam menampung beban lalulintas berkurang serta ditambah dengan peningkatan pada volume kendaraan, semua hal tersebut berkolaborasi dalam menurunkan nilai kinerja jalan sehingga jalan Menteri Supeno mengalami penurunan kualitas.

\section{KESIMPULAN}

\subsection{KESIMPULAN}

Pada analisis aktivitas PKL stabilisasi shelter Manahan yang memicu bangkitan, pergerakan pada ruas jalan Menteri Supeno teridentifikasi empat hal yang dapat memicu bangkitan pergerakan diataranya adalah waktu pelayanan, skala pelayanan, pola sebaran memanjang dan homogenitas jenis dagangan. Keempat hal itu menyebabkan terjadinya bangkitan pergerakan menuju ruas jalan Menteri Supeno. Adanya bangkitan pergerakan dapat dilihat melalui volume kendaraan. Pada analisis volume kendaraan Jl. Menteri Supeno terbagi menjadi dua penggal jalan yaitu penggal jalan dengan PKL stabilisasi dan penggal jalan tanpa PKL stabilisasi. Hasil analisis membuktian bahwa pagi hari memiliki volume lebih besar dari pada siang dan sore hari. Selain itu, pada penggal jalan dengan PKL stabilisasi volume kendaraan lebih besar dari pada penggal jalan tanpa PKL stabilisasi.

Pada analisis parkir on street jalan Menteri Supeno terdapat lima komponen diantaranya adalah volume parkir, akumulasi parkir, rata-rata lama parkir, kapasitas parkir dan indeks parkir. Kelima komponen menghasilkan bahwa parkir on street secara signifikan menurunkan kapasitas jalan Menteri Supeno khusunya pada penggal jalan dengan PKL stabilisasi. Pada analisis kapasitas jalan Menteri Supeno terbagi menjadi dua penggal jalan yaitu penggal jalan dengan PKL stabilisasi dan tanpa PKL stabilisasi. Hasil analisis membuktian bahwa pada penggal jalan dengan PKL stabilisasi mengalami penurunan kapasitas yang cukup siginfikan dibandingkan dengan penggal jalan tanpa PKL stabilisasi dengan besar selisih sebesar 1347 smp/jam. Perbedaan nilai tersebut mencapai hampir $50 \%$.

Pada analisis kinerja jalan Menteri Supeno terbagi menjadi dua penggal jalan yaitu penggal jalan dengan PKL stabilisasi dan tanpa PKL stabilisasi. Hasil analisis membuktian bahwa pada penggal jalan tanpa PKL stabilisasi kondisi kinerja jalan dalam kondisi aman dan tidak mengalami gangguan, dengan nilai kurang dari 0,45 . Sedangkan, pada penggal jalan dengan PKL stabilisasi mengalami kondisi bervariasi, mulai dari kondisi sedikit hingga banyak gangguan, dengan rentang nilai terbesar 0,9-1,0 yaitu kinerja jalan kurang baik, kendaraan berjalan dengan banyak hambatan.

Pada analisis pengaruh stabilisasi PKL Manahan terhadap kinerja jalan Menteri Supeno dihasilkan bahwa adanya aktivitas PKL stabilisasi menyebabkan terjadi bangkitan pergerakan, kemudian adanya bangkitan pergerakan mempengaruhi besar nilai volume kendaraaan. Selanjutnya, adanya fasilitas PKL stabilisasi berupa parkir on stret secara siginfikan menurunkan nilai kapasitas jalan. Adanya kecenderungan-kecenderungan tersebut menyebabkan nilai kinerja jalan Menteri Supeno turun khususnya pada penggal jalan dengan PKL stabilisasi.

\subsection{REKOMENDASI} berikut :

Berdasarkan temuan lapangan dan kesimpulan yang telah dijelaskan, penulis memberikan rekomendasi sebagai

1) Untuk pemerintah setempat,

Dalam melaksanakan sebuah program penataan PKL salah satunya yaitu program stabilisasi PKL, perlu adanya upaya penataan pada parkir on street agar tidak menimbulkan permasalahan baru pada program stabilisasi, salah satu alternatif rencanannya dengan memindahkan lahan parkir pada kawasan baru mungkin bisa pada gedung di sekitar lokasi stabilisasi PKL. Adanya rekomendasi ini diharapkan tidak ada lagi program penataan PKL dari pemerintah yang harusnya mengurangi dampak negatif namun menimbulkan permasalahan baru.

2) Untuk penelitian selanjutnya,

Penelitian ini dibatasi untuk spesifik meneliti kaitan antaran PKL dengan sektor transportasi yang mendetil pada pengaruh keberadaan PKL stabilisasi terhadap kinerja jalan Menteri Supeno, sehingga perlu adanya penelitian lanjutan yang meneliti kaitannya terhadap aspek lain seperti pengaruh stabilisasi PKL terhadap bangkitan pergerakan transportasi atau terhadap kapasitas jalan Menteri Supeno. Selain itu, objek pada penelitian ini hanya membahas pada program stabilisasi shelter sedangkan di Kota Surakarta terdapat program stabilisasi yang lain seperti stabilisasi PKL 
grobak dan stabilisasi PKL tenda yang memiliki waktu pelayanan di malam hari. Pengaruh keberadaan PKL stabilisasi Manahan terhadap kinerja jalan Menteri Supeno di masa yang akan datang juga perlu untuk diteliti sebagai perbandingan dan keberlanjutan dari penelitian ini.

\section{DAFTAR PUSTAKA}

Buku

Hariyono, P. 2007. Sosiologi Kota untuk Arsitek. Jakarta : PT Bumi Aksara

McGee, T.G dan Y.M.Yeung. 1977. Hawkers in Southeast Asian Cities: Planning For The Bazaar Economy. Ottawa: International Development Research Centre (IDRC).

Tamin, Ofyar Z. 2000. Perencanaan dan Permodelan Transportasi. Bandung: Jurusan Teknik Sipil Institut Teknologi Bandung

Warpani, S. 1990. Rekayasa Lalu Lintas. Jakarta: Bhatara Karya Aksara.

Jurnal

Edward, L, G. 2010. Aglomeration Economics. Chicago : The University of Chicago Press

Haryanti, D. 2008. Kajian Pola Pemanfaatan Ruang Terbuka Publik Kawasan Bundaran Simpang Lima. Megister Teknik Perencanaan Wilayah dan Kota. Semarang: UNDIP

Mataram, N, K. 2011. Analisis Kinerja Ruas Jalan Akibat Bangkitan Pergerakan di Pasar Pandak Gede. Denpasar: Fakultas Teknik Universitas Udayana

Rahayu,M.J et al. 2014. Model Zonasi Lokasi PKL yang Berkelanjutan dalam Mendukung Pengentasan Kemiskinan di Kota Surakarta. UNS Surakarta.

Ray, C. N. And Mishra, Assem. 2011. Vendors and Informal Sector A Case-Study of Street Vendors of Surat City. India : Faculty of Planning and Public Policy CEPT University

Roever, Sally. 2014. Informal Economy Monitoring Study Sector Report : Street Vendors. Cambridge, MA, USA : WIEGO

Wahyuni, Rida. 2008. Pengaruh Parkir pada Badan Jalan Terhadao Kinerja Ruas Jalan (Studi Kasus : Jalan Brigjen Katamso Sekolah Harapan Mandiri Mendan). Medan: Universitas Sumatera Utara

\section{Dokumen Pemerintah yang Tersedia Online}

Direktorat Jendral Bina Marga, 1997. Manual Kapasitas Jalan Indonesia. Jakarta: Departemen Pekerjaan Umum.

Peraturan Daerah Kota Surakarta Nomor 3 Tahun 2008 tentang Pengelolaan Pedagang Kaki Lima

Rencana Tata Ruang Wilayah Kota Surakarta Tahun 2011-2031 